\title{
Law Development Of Waqf Al-Nuqud (Cash Waqf) Towards Electronic Waqf (E-Waqf) Based On Public Welfare
}

\author{
Ong Argo Victoria ${ }^{1}$; Esmi Warassih Pujirahayu ${ }^{2}$; Akhmad Khisni ${ }^{3}$ and Russel Ong ${ }^{4}$
}

\begin{abstract}
The modern era is identified with the era of the technology and the digital society. Every human activity will be driven through a series of digital technology system. For example everything is use electronic through the internet system such as identification number Electronic Identity Card (E-ID), Card payment toll road electronic (E-Toll), ATM, Personal Identification number (PIN), etc. all using the digital system. No exception waqf management innovation has also been happening in Islamic countries including Kuwait, Qatar, Emirates, Jordan, Saudi Arabia, Egypt, Turkey, Bangladesh, Malaysia, Singapore, and even Europe and America. Among the endowments with a paradigm shift arrangements progressive approach fairly fundamental law, among others, first, in the case of an asset in waqf no longer confined to immovable property, but also against movable property. Evidence used to reinforce this view, as formulated in Article 16 Paragraph (1) of Act No. 41 of 2004 on Endowments or Waqf, which reads " the treasure can be used in waqf is immovable and also moving objects", so it open the opportunity that te electonical waqf (E-Waqf) which use technology system can be applicated. This article aims to make an overview on the developing of law on waqf al-nuqud towards electronic waqf (e-waqf) to realize the public welfare especially for people of Indonesian country.

Keywords: Law Development; Waqf Al-nuqud; E-Waqf; Welfare.
\end{abstract}

\section{Introduction}

Technology showed the phenomenon in society as impersonal and autonomous transform every aspect of human life into a technical scope. Human interaction is driven by an all-digital technology: computers, internet, ATM machines, telephones, mobile phones, and so on, all of them driven digitally. We can buy something simply by swiping an ATM card and PIN pressing a few numbers, such as hotel rooms to pay bills, buy tickets, and so on. Remittances can be done in seconds with just a few digits of the value of money to be sent and multiple-digit account number. Not the money sent, but only a series of numbers that move from one account to another. Connected with the social problems of Indonesian society and the demand for economic prosperity in recent years, the existence of money or cash waqf has become very strategic. Besides as one aspect of Islamic teachings that have spiritual dimension, cash waqf is also a teaching that emphasizes the importance of economic welfare (social dimension) and welfare of

\footnotetext{
${ }^{1}$ Reseacher of International Islamic University Malaysia and Student's Doctor of Law, Sultan Agung Islamic University in Semarang, email: argovictoriaupin@gmail.com

2 Professor in law and the Promoter, Sultan Agung Islamic University in Semarang.

${ }^{3}$ Co-Promoter, Sultan Agung Islamic University in Semarang.

${ }^{4}$ National Taiwan Normal University, email: rsslong@gmail.com
} 
the people. ${ }^{5}$

Effective management of cash waqf for the welfare of society is an inevitable demand. Especially in this time Indonesia experienced an economic crisis that requires the participation of many parties. The birth of the Act of the Republic of Indonesia No. 41 of 2004 on Waqf directed to empower waqf which is one of the instruments in building the socio-economic life of Muslims. The presence of Waqf Law is a momentum of waqf empowerment productively, because it contains a comprehensive understanding and management pattern of potential empowerment of waqf in a modern way use E-Waqf.

\section{Research Method}

This is the Socio-Legal research with progressive and hermeneutics approach, which is based on legal norms and the theory of the existing legal enforceability. ${ }^{6}$ Reviewing the juridical law from the standpoint of sociology and Hermeneutics as the Interpretation Understanding. ${ }^{7}$

\section{Discussion}

\subsection{Overview of Cash Waqf}

The Act RI No. 41 of 2004 on Waqf covers immovable and movable property, including waqf of money (Cash Waqf) which is very wide use, not limited to the establishment of places of worship and social religious. Such a legal formulation, obviously a very revolutionary change and if it can be realized will have a multiplier effect, especially in relation to the economic empowerment of Muslims. ${ }^{8}$

The MUI's Fatwa was then reinforced by the presence of Act No.41 of 2004 about Waqf stating that waqf is not only immovable objects, but also movable object, like money. In addition, the regulated waqf policy in Indonesia, ranging from the formation of nadzir (manager) to the management of waqf property. In order to carry out its function, this Law still requires other tools, namely Government Regulation and Minister of Religious Regulation concerning Waqf of Money which will be the operational guideline in implementation, and the existence of Indonesian Waqf Institution (BWI) which will serve as central nadzir of waqf. After going through a long process, at the end of 2006 issued Government Regulation No. 42 of 2006 On the Implementation of Waqf. After that, in July 2007 promulgated the Act of Presidential Decree of the Republic of Indonesia No. 75 of

\footnotetext{
5 Directorate of Waqf of Islamic Community, 2008, New Waqf Paradigm in Indonesia, Jakarta, p.1.

${ }^{6}$ Alimuddin, Applications Legal Reform in the Theory of Socio Legal Studies, Director General of Courts, www.badilag.net, Accessed December 26, 2018. (IIUM Malaysia)

${ }^{7}$ Esmi Warassih 2005, Institution Law: A Sociological Assessing, Suryandaru Utama, Semarang, p. 2324.

8 Achmad Djunaidi, 2009, Towards Waqf Productive, Mumtaz Publishing, Depok, p.90.
} 
2007 which decided and raised the membership of BWI period 2007-2010.

In addition, the MUI has issued its Fatwa on cash waqf on May 11, 2002, stating that: 1) Cash waqf (Waqf al-nuqud) is a waqf by a person, group, institution or legal entity in the form of the money; Included in the sense of money are securities; Waqf the jawāz is legal (allowed); Cash Waqf may only be channeled and used for syar'iyyah permitted matters; and The basic value of Cash Waqf must be guaranteed to be sustainable, not to be sold, granted and/or inherited.

The birth of Act No.41 of 2004 about Waqf, Fatwa of The Indonesian Ulama Council and its derivative regulation are the starting point of increasing the potential of waqf in Indonesia to a more productive direction within the framework of Indonesian fiqh. Act No.41 of 2004 about Waqf also a momentum of waqf empowerment productively because it contains a comprehensive understanding and management pattern of potential empowerment of waqf in a modern way. In the new waqf legislation the concept of waqf contains a very wide dimension. It includes immovable property, as well as movable, including cash waqf whose use is very wide, not limited to the establishment of places of worship and religious social. ${ }^{9}$

\subsection{Cash Waqf in Indonesian Law Perspective}

In Article 16, paragraph 3, of Act No. 41 of 2004 on Waqf, which can endowment Moving Bodies, namely10: 1) Money; Precious metal; Securities; Vehicle; Intellectual Property Rights; Rental Rights; and Other moving objects in accordance with the provisions of sharia and legislation in force. Furthermore, regarding the position of the treasure after endowment in progressive paradigm can be seen from the definition of waqf contained in Article 1 Paragraph (1) of Act No. 41, 2004. The article states that the endowment is a legal act wakif to separate and / or hand over part of their wealth either permanently or for a certain period in accordance with their interests for purposes of worship and / or the general welfare according to sharia.

Conceptually, the cash waqf has a unique opportunity to create investments in religious, educational, and social services. Savings from people with middle to upper income can be utilized through exchange with the Cash Waqf Certificate (CWC), while income derived from cash waqf management can be spent for various purposes, including for the maintenance and management of the waqf of land. Mustofa Edwin Nasution describes how to exploit the potential of CWC excavated

\footnotetext{
9 Agustianto, 2010, Endowments of Welfare and Improvement of People's Welfare, published in August.

${ }^{10}$ Budi, Faith Setya, Revitalization Endowments as Community Economic Activator, in journals: AlIqtishadiyah Islamic Economics and Law Journal of Islamic Economics, Volume: II, Number II. June 2015
} 
in Indonesia, namely: ${ }^{11}$

a. The scope of the money-donor's audiences can be very broad compared to the usual waqf.

b. Cash Waqf Certificate can be made various kinds of fractions, tailored to the segment of Muslims that allows to arouse the spirit of charity (sadaqah jāriyah), for example Rp. 10.000,- and Rp.25.000,-

Mustafa Edwin Nasution once assumed that the number of middleclass Muslim population in Indonesia is 10 Million with average monthly income between Rp 5000 (five hundred thousand rupiahs) Rp10.000.000 (ten million rupiahs) can be calculated as follows: The explanation is if the Muslims who earn Rp500.000 4 Million people and each year each waqf Rp60.000 then each year accumulated Rp 240 Billion:

a. If people who earn Rp1.000.000-Rp2.000.000 totaling 3 Million people and each year each Rp120.000 each time accumulated funds amounting to Rp 360 Billion

b. If people who earn Rp2.000.000-Rp5.000.000 a total of 2 Million people and each year each with Rp600.000 then each year accumulated funds as much as Rp 1,2 Trillion

c. If people who earn Rp5.000.000-Rp10.000.000 a total of 1 Million people and each year each with Rp1.200.000 then each year accumulated funds as much as Rp 1,2 Trillion

Consequently, waqf accumulated for one year amounting to Rp 3 Trillion Based on the example of the above calculations, it is evident that the success of the institution to mobilize waqf funds will greatly determine the benefits of a waqf institution, which is a problem, the money cannot be directly granted to mawqu $f$ 'alayh, but nadzir (manager) must manage and develop it first.

The potential of cash waqf especially use E-Waqf is huge if it can be managed properly. Especially if the funds are handed over to professional managers and invested in productive sectors so that such funds can be used for productive and economic activities in order to assist the people and interests of the people. Thus the amount of cash waqf will not decrease, but increase and continue. If cash waqf is deposited at Islamic Banking and every year is awarded 9\% profit sharing, then at the end of the year will be obtained investment fund Rp. 270.000.000.000.12

As a follow-up from the birth of Act No.41 of 2004 on Waqf, currently in Indonesia many Islamic Banking and Waqf Management Institutions launched products and facilities that collect money from cash waqf from society. Like Bait alMal Muamalat who launched Cash waqf Muamalat, "Dompet Dhuafa Republika"

11 Muhammad Syafii Antonio, Islamic Banking as Waqaf Fund Manager (Workshop International Paper, Empowerment of People's Economy through Productive Waqf, at Wisma Haji Batam, 7-8 January 2002), p.4. 12 Indonesian Ulama Council (MUI), 2002, Fatwa on Endowment of Money of 2002, MUI, Jakarta. 
which launched the Indonesian Waqf Fund, and a National Waqf Institution formed based on the Act on Waqf in 2007 that is Indonesian Endowment Agency 22.

In the view of the purpose and contribution that can be given by the institution of cash waqf, the existence of cash waqf in Indonesia becomes very crucial. At least there are some things that lead to the importance of cash waqf in Indonesia ${ }^{13}$ :

1) The poverty rate in Indonesia is still high, which needs attention and concrete steps

2) High gap between rich and poor society

3) Indonesia has the largest number of Muslim population, so waqf has great potential to be developed

4) A number of disasters that occur, resulting in a deficit APBN (National Budget), so it takes the independence of society in the procurement of public goods.

\section{Conclusion}

The inclusion of cash waqf in the legislation of the Republic of Indonesia through Act No.41 of 2004, is a fresh breeze and a new opportunity for Indonesian Muslims to manage and develop a potential fund of large enough people with productive and professional in improving the economic welfare of the Muslims and release Muslims from poverty to get the public welfare.

\section{Bibliography}

[1] Directorate of Waqf of Islamic Community, 2008, New Waqf Paradigm in Indonesia, Jakarta.

[2] Alimuddin, Applications Legal Reform in the Theory of Socio Legal Studies, Director General of Courts, www.badilag.net, Accessed December 26, 2018. (IIUM Malaysia)

[3] Esmi Warassih 2005, Institution Law: A Sociological Assessing, Suryandaru Utama, Semarang.

[4] Achmad Djunaidi, 2009, Towards Waqf Productive, Mumtaz Publishing, Depok.

[5] Agustianto, 2010, Endowments of Welfare and Improvement of People's Welfare, published in August.

[6] Budi, Faith Setya, Revitalization Endowments as Community Economic Activator, in journals: Al-Iqtishadiyah Islamic Economics and Law Journal of Islamic Economics, Volume: II, Number II. June 2015

[7] Muhammad Syafii Antonio, Islamic Banking as Waqaf Fund Manager (Workshop International Paper, Empowerment of People's Economy through Productive Waqf, at Wisma Haji Batam, 7-8 January 2002).

[8] Indonesian Ulama Council (MUI), 2002, Fatwa on Endowment of Money of 2002, MUI, Jakarta. 